\title{
Disposisi Matematis Siswa SD Melalui Model Pembelajaran Thinking Aloud Pairs Problem Solving
}

\author{
Jayanti Putri Purwaningrum \\ Pendidikan Guru Sekolah Dasar, Fakultas Keguruan dan Ilmu Pendidikan \\ Universitas Muria Kudus \\ Email: jayanti.putri@umk.ac.id
}

\begin{abstract}
ABSTRAK.Tujuan dilakukannyapenelitian ini yaituuntuk mengkaji peranan model pembelajaran TAPPS(Thinking Aloud Pairs Problem Solving) yang diterapkan pada siswa terhadap peningkatan disposisi matematis. Jenis penelitian yang dilakukan yaitu pre experimental design dengan desain penelitiannya one group pretest-posttest. Subjek penelitiannya adalah siswa kelas V SD NU Nawa Kartika, Kabupaten Kudus, Jawa Tengah. Instrumen yang digunakan yaitu perangkat pembelajaran,lembar observasi siswa dan skala disposisi matematis. Data dianalisis dengan menggunakan Normalized-Gain. Hasil studi penelitian menunjukkan bahwa penerapan model pembelajaran TAPPS dapat meningkatkan disposisi matematis siswa.
\end{abstract}

Kata Kunci:Matematika, Disposisi Matematis, TAPPS

\section{PENDAHULUAN}

Matematika adalah mata pelajaran yang harus dipelajari siswa mulai dari Sekolah Dasar (SD). Tujuan dari pembelajaran matematika sesuai dengan Depdiknas (2006) yaitu siswa dapat memiliki kemampuan memahami konsep matematika, menjelaskan keterkaitan antar konsep dan mengaplikasikan konsep atau algoritma secara akurat, efisien, dan tepat dalam mengkomunikasikan gagasan dengan simbol, tabel, diagram atau media lain untuk memperjelas masalah. Selain itu, siswa juga dituntut untuk berpikir logis sekaligus menerapkan tahapan deduktif ketika menyelesaikan masalah dalam kehidupan sehari-hari. Tujuan tersebut akan tercapai, apabila siswa menguasai berbagai kemampuan matematis. Lima kemampuan matematis yang dijelaskan dalam kurikulum KTSP 2006 (Depdiknas, 2006) diantaranya adalah: (1) kemampuan pemahaman matematis; (2) kemampuan komunikasi matematis; (3) kemampuan penalaran matematis; (4) kemampuan representasi matematis; dan (5) kemampuan pemecahan masalah matematis.

Selain bertujuan untuk mengembangkan kemampuan kognitif, matematika juga digunakan untuk mengembangkan kemampuan afektif. Hal ini penting sebab menurut Popham (Depdiknas, 2008) prestasi belajar siswa juga ditentukan oleh kemampuan afektif. Kemampuan afektif pada matematika yaitu memiliki sikap menghargai fungsi matematika dalam kehidupan sehari-harinya antara lain memiliki rasa ingin tahu, minat, perhatian terhadap materi matematika, serta percaya diri dan ulet dalam menyelesaikan masalah. Dalam pembelajaran matematika, kemampuan afektif tersebut lebih dikenal dengan disposisi matematis.

Sumarmo (2005) menjelaskan bahwa disposisi matematis adalah keinginan, kesadaran dan dedikasi yang kuat pada diri siswa untuk belajar matematika dan melaksanakan berbagai kegiatan matematika. Di pihak lain, Permana (2010) berpendapat disposisi matematis siswa dikatakan baik apabila mereka menyukai masalah yang menantang dan terlibat secara langsung dalam memecahkan atau menyelesaikan masalah itu. Selain itu, siswa juga merasakan bahwa mereka mengalami proses belajar saat menyelesaikan tantangan tersebut. Dalam prosesnya siswa merasakan munculnya kepercayaan diri, pengharapan dan kesadaran untuk melihat kembali hasil berpikirnya. Dengan demikian, disposisi matematis siswa sangat penting untuk dimiliki. Akan tetapi kenyataannya, pada saat ini, pengembangan disposisi matematis tersebut belum maksimal.

Studi yang dilakukan oleh Nila (2010) pada siswa SMP di Palembang menunjukkan bahwa disposisi matematis siswa rendah. Hal ini dikarenakan pembelajaran lebih terpusat pada guru dimana guru 
menstransfer semua informasi dan siswa hanya menerima informasi yang dijelaskan oleh guru. Hal ini mengakibatkan dalam proses pembelajaran siswa menjadi pasif. Kecenderungan siswa untuk tidak suka terhadap mata pelajaran matematika diungkapkan oleh Hidayah (2014) dalam penelitiannya di Jogjakarta. Hidayah (2014) juga menambahkan bahwa siswa hanya belajar matematika saat akan meghadapi ulangan harian atau ujian saja dan mereka lebih suka menyibukkan diri pada kegiatan yang lain.

Berdasarkan hasil observasi di SD NU Nawa Kartika, Kabupaten Kudus diperoleh informasi bahwa sebagian besar siswa menyatakan matematika adalah pelajaran yang sulit dan menakutkan. Selama proses pembelajaran matematika, guru masih menerapkan pembelajaran ekspositori dimana orientasi pembelajaran lebih kepada teacher centered dibandingkan student centered. Pembelajaran tersebut difokuskan pada proses prosedural yang kurang memberikan peluang siswa untuk mengembangkan berbagai kemampuan matematis. Ketika siswa dituntut untuk menyelesaikan soal berpikir tingkat tinggi, mereka lebih cepat menyerah dan malas untuk mengerjakan soal tersebut padahal mereka belum mencoba menyelesaikannya. Dengan demikian, rasa percaya diri, keingintahuan dan sikap positif siswa terhadap mata pelajaran matematika kurang. Hal itu dikuatkan dengan pendapat Syaban (2009) yang mengungkapkan bahwa dewasa ini, daya dan disposisi matematis siswa belum tercapai sepenuhnya.

Kekurangberhasilan pembelajaran matematika disebabkan pula oleh faktor keaktifan siswa. Pembelajaran ekspositori yang sering dilakukan memberikan dampak siswa tidak aktif karena peran guru di dalam kelas lebih mendominasi, siswa hanya mencatat dan mendengarkan materi yang disampaikan guru sehingga keaktifan siswa pada kegiatan belajar mengajar tidak ada. Padahal menurut pendapat Krismanto (2003) siswa disebut aktif apabila terdapat mobilitas yang nampak dari hasil interaksi antara siswa dan guru atau antara siswa-siswa itu sendiri.

Keaktifan siswa pada pembelajaran matematika sangat diharapkan sebab akan berdampak pada ingatan mereka sehingga konsep yang dipelajari dapat bertahan lebih lama. Muslich (2008) mengemukakan bahwa suatu konsep dapat mudah untuk diingat dan dipahami manakala konsep tersebut disajikan dengan tahap-tahap yang jelas, tepat dan menarik. Pada hakikatnya, semua siswa mempunyai potensi untuk mencapai kompetensi. Apabila tidak kompetensi tidak tercapai, hal tersebut bukan disebabkan siswa tidak mempunyai kemampuan untuk mencapainya tetapi dikarenakan tidak tersedianya pengalaman belajar yang televan sesuai dengan karakteristik masing-masing siswa.

Untuk mengukur disposisi matematis, Syaban (2009) menjelaskan beberapa indikator yang harus digunakan, antara lain: (1) menunjukkan minat atau antusias untuk belajar matematika; (2) menunjukkan perhatian yang serius dalam mempelajari matematika; (3) menunjukkan kegigihan dalam menghadapi permasalahan; (4) menunjukkan rasa percaya diri dalam belajar dan memecahkan masalah; (5) menunjukkan rasa ingin tahu yang tinggi; dan (6) menunjukkan kemampuan untuk berbagi dengan orang lain. Di pihak lain, NCTM (1989) menjelaskan disposisi matematis terdiri dari tujuh komponen, yaitu: (1) percaya diri dalam menggunakan matematika, mengkomunikasikan ide-ide dan memberi alasan; (2) fleksibel dalam mengeksplorasi ide-ide matematis dan mencoba berbagai metode alternatif untuk memecahkan masalah; (3) bertekat kuat, gigih, ulet dalam menyelesaikan tuga-tugas matematika; (4) ketertarikan, keingintahuan dan kemampuan dalam bermatematika; (5) melakukan refleksi diri terhadap cara berpikir; (6) menghargai aplikasi matematika; dan (7) mengapresiasi peranan matematika.Mahmudi (2010) berpendapat bahwa disposisi matematis diperlukan siswa untuk bertahan ketika menghadapi masalah, mengambil tanggung jawab dan membiasakan kerja yang baik dalam matematika sehingga menjadi salah satu faktor penunjang keberhasilan prestasi belajar matematika siswa. Oleh karena itu menurut Merz (2009), perlu perhatian serius terhadap pengajaran dan diposisi matematis sebab keduanya adalah hal yang sangat penting, sehingga eksplorasi aspek pengembangan tersebut sangat diperlukan. Disini, peran dan persepsi guru memainkan peran penting dalam rangka mengembangkan diposisi matematis siswa.

Pada dasarnya, kebiasaan berpikir dan sikap yang baik akan dapat mengembangkan disposisi matematis siswa. Dengan demikian, perlu adanya pembelajaran inovatif yang dapat mendukung pengembangan disposisi tersebut, salah satunya yaitu dengan menerapkan model TAPPS (Thinking Aloud Pairs Problem Solving). Barkey (2012) menjelaskan bahwa TAPPS merupakan inovasi pembelajaran dimana pelaksanaannya menggabungkan dua model pembelajaran yaitu model pembelajaran pemecahan masalah dan model pembelajaran kooperatif yang melibatkan siswa secara aktif dalam pembelajaran sehingga mereka dapat lebih memahami materi secara mendalam.

Aktivitas siswa dalam model TAPPS dilakukan pada kelompok kecil dengan anggota dua orang siswa yang heterogen. Hal tersebut dimasudkan agar terjadi interaksi yang positif antara siswa yang satu dengan yang lainnya sehingga rasa percaya diri siswa ketika menyelesaikan masalah dapat meningkat. 
Setelah siswa dikelompokkan kemudian mereka dituntut untuk menyelesaikan masalah dimana antara dua siswa diberikan peran yang berbeda pada setiap masalah, salah satu dari mereka menjadi problem solver (PS)sedangkan yang lain menjadi listener (L). Peran guru dalam penerapan model ini yaitu mengkondisikan siswa sehingga mereka memiliki rasa ingin tahu, percaya diri dan semangat ketika menyelesaikan masalah.

Peran PS yaitu mengutarakan proses analisis yang diterapkan ketika menyelesaikan masalah matematis yang berupa tulisan sekaligus dengan penjelasannya. PS terus menerus akan membuat $\mathrm{L}$ memahami terhadap proses yang dipilihnya sedangkan L berusaha mendorong PS agar dapat berpikir dan menjelaskan tahapan penyelesaian masalah secara jelas. Dalam hal ini L diperbolehkan mengajukan koreksi dan memberi saran namun harus tetap menahan diri untuk ikut menyelesaikan masalah. Kondisi ini melatih siswa untuk menyampaikan semua gagasan yang dia miliki dalam menyelesaikan masalah. Dari hasil diskusi kelompok, kesimpulan atau solusi yang disertai bukti penyelesaian masalah dapat dibuat oleh siswa secara mandiri.

Penelitian yang dilakukan oleh Naryestha dkk (2014) di kelas V SD Gugus Kompyang Sujana, Denpasar menghasilkan bahwa terdapat perbedaan yang signifikan antara siswa yang belajar dengan menggunakan model pembelajaran TAPPS dengan siswa yang belajar menggunakan pembelajaran konvensional. Model tersebut memberikan pengaruh yang optimal terhadap hasil belajar matematika siswa. Ketika mengikuti pembelajaran dengan model TAPPS siswa dapat mengungkapkan gagasan, berdiskusi, menemukan konsep sendiri sehingga materi mudah diingat, dan belajar memecahkan masalah serta saling bekerja sama. Selain itu siswa juga merasa senang belajar matematika sebab suasananya menyenangkan sehingga mereka tidak lagi menganggap matematika adalah salah satu pelajaran yang tidak mudah dan menyeramkan. Peningkatan disposisi matematis siswa yang menggunakan pembelajaran inovatif juga diungkapkan oleh Mahmuzah dkk (2014). Lebih lanjut, Mahmuzah dkk (2014) menjelaskan bahwa secara keselurahan disposisi siswa meningkatkan secara signifikan dan hasilnya pun lebih baik daripada siswa yang belajar dengan menerapkan pembelajaran konvensional.

Berdasarkan uraian yang telah disajikan, latar belakang dalam penelitian ini yaitu apakah penerapan model pembelajaran TAPPS pada siswa di SD NU Nawa Kartika dapat meningkatkan disposisi matematis? Dengan demikian, tujuan dari penelitian ini yaitu penulis berupaya untuk mengkaji apakah penerapan model pembelajaran TAPPS pada siswa di SD NU Nawa Kartika dapat meningkatkan disposisi matematis. Indikator disposisi matematis yang dikaji dalam penelitian ini yaitu: (1) percaya diri terhadap kemampuan yang dimiliki; (2) terbuka jika mendapat masukan dari orang lain; (3) teliti dan tekun dalam menyelesaikan masalah; (4) memiliki motivasi untuk bertanya tentang hal baru dan menjawab setiap pertanyaan; (5) mampu menyimpulkan dan membuat rangkuman; (6) kemampuan berpendapat secara matematis dan mampu memberikan contoh dalam kehidupan sehari-hari; dan (6) mampu mengkoneksikan matematika dengan ilmu lain.

\section{METODE PENELITIAN}

Metode penelitian yang digunakan dalam penelitian ini adalah metode pre experimental design. Hal ini dikarenakan penelitian yang dilakukan hanya menggunakan satu kelompok eksperimen yaitu kelompok siswa yang menerapkan pembelajaran dengan model TAPPS. Desain penelitian yang dilakukan adalah one group pre test-post test (desain pretes dan postes sebuah kelompok). Dengan demikian, pada kelas penelitian diberikan pretest sebelum perlakuan diberikan. Kemudian setelah perlakuan diberikan, pada kelompok tersebut diberikan pula posttest. Tugas yang diberikan pada saatpretestdan posttest merupakan tugas yang serupa. Secara ringkas, Ruseffendi (2010) menggambarkan desain tersebut adalah sebagai berikut:

O $\quad \mathrm{O}$

Keterangan:

$\mathrm{O} \quad=$ Pretest dan posttestdisposisi matematis siswa

$\mathrm{X}=$ Pembelajaran matematika menggunakan model TAPPS

Populasi penelitian in adalah seluruh siswa SD NU Nawa Kartika Kabupaten Kudus, dengan sampel yang diambil terdiri dari satu kelas yaitu kelas V. Instrumen penelitian yang digunakan dalam penelitian ini yaitu perangkat pembelajaran yang terdiri dari silabus, Rencana Pelaksanaan Pembelajaran (RPP), dan Lembar Kerja Siswa (LKS). Perangkat pembelajaran tersebut dirancang oleh peneliti berdasarkan pembelajaran yang digunakan yaitu model TAPPS. Selain perangkat pembelajaran, peneliti juga menggunakan instrumen non tes berupa lembar observasi siswa dan skala disposisi matematis. Lembar observasi pada penelitian ini digunakan untuk memperoleh gambaran tentang suasana 
pembelajaran yang berkaitan dengan aktivitas siswa. Sedangkan skala disposisi matematis digunakan untuk mengumpulkan data disposisi matematis siswa.

Prosedur yang digunakan dalam penelitian ini terdiri dari empat bagian, yakni: (1) Tahap persiapan; (2) Tahap pelaksanaan; (3) Tahap analisis data; dan (4) Tahap pembuatan kesimpulan. Pada tahap persiapan dilakukan serangkaian kegiatan, yaitu: (1) Melakukan observasi ke sekolah; (2) Menyusun dan menetapkan pokok bahasan yang digunakan dalam penelitian; (3) Menyusun rencana pelaksanaan pembelajaran dan perangkat pembelajaran (Silabus, RPP, dan LKS); (4) Menyusun instrumen penelitian; (5) Melakukan uji coba instrumen penelitian dan (6) Analisis uji coba instrumen.

Kegiatan yang dilakukan pada tahap pelaksanaan penelitian yaitu: (1) Memberikan pretest disposisi matematis siswa pada kelas penelitian; (2) Melaksanakan kegiatan pembelajaran melalui model TAPPS; (3) Melaksanakan observasi pada kelas penelitian ketika pembelajaran berlangsung. Kegiatan observasi dibantu oleh satu orang observer untuk mengobservasi kegiatan pembelajaran; dan (4) Melaksanakanposttest disposisi matematis siswa. Kemudian, setelah data penelitian terkumpul, pada data yang diperoleh tersebut dilakukan analisis data. Tahapan terakhir dalam penelitian yaitu menarik kesimpulan dan menyusun laporan penelitian. Untuk mengetahui peningkatan disposisi matematis siswa, data disposisi matematis siswa dalam penelitian ini dianalisis dengan menggunakan rumus gain ternormalisasi (Normalized Gain) yang dikembangkan oleh Hake (Meltzer, 2002).

\section{HASIL PENELITIAN DAN PEMBAHASAN}

Hasil perhitungan terhadap skala disposisi matematis siswa pada kelas penelitian disajikan pada Tabel 1 berikut.

Tabel 1. Hasil Perhitungan Skala Disposisi Matematis Siswa

\begin{tabular}{ccccc}
\hline & Pretest & Posttest & Normalized Gain & Keterangan \\
\hline Disposisi Matematis & 73 & 83 & 0,37 & Sedang \\
\hline
\end{tabular}

Berdasarkan Tabel 1 diperoleh data bahwa Normalized Gain disposisi matematis siswa adalah 0,37. Dengan demikian, peningkatan disposisi matematis siswa dapat diklasifikasikan pada kriteria sedang. Peningkatan ini disebabkan oleh tahapan pada model TAPPS yang membuat siswa lebih paham tentang materi yang disajikan guru dan mereka turut aktif selama proses pembelajaran. Pada saat pembelajaran, guru tidak hanya memberikan materi matematika tetapi juga juga mendorong dan memfasilitasi siswa untuk mengkonstruk pengetahun yang diterima secara mandiri. Hal ini mengakibatkan mereka harus berperan aktif pada saat pembelajaran dalam membangun sebuah pengetahuan.

Hasil perhitungan Tabel 1 dikuatkan oleh hasil yang didapat dari lembar observasi siswa pada pertemuan ke satu sampai dengan pertemuan ketiga yang secara ringkas dapat dilihat pada Gambar 1 berikut.

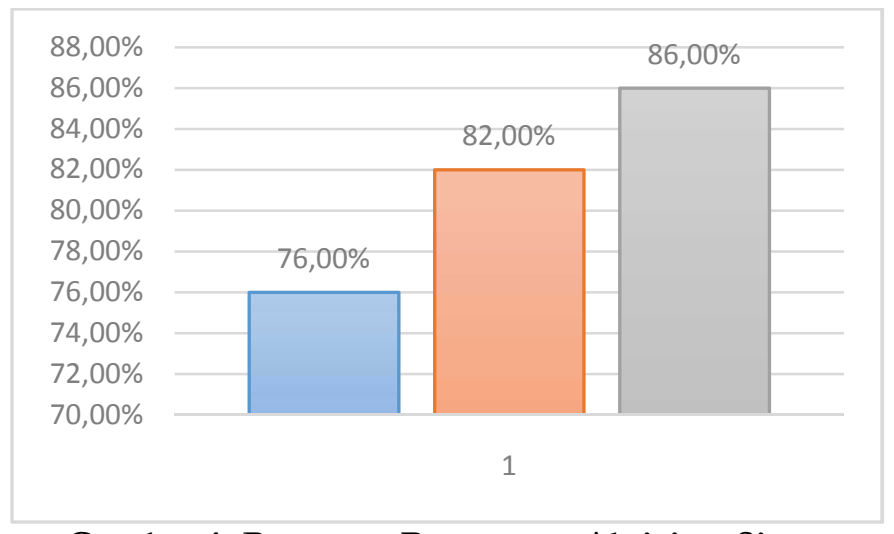

Gambar 1. Rata-rata Persentase Aktivitas Siswa

Hasil pada Gambar 1 menunjukkan bahwa secara keseluruhan aktivitas siswa dari pertemuan pertama sampai pertemuan ketiga sudah baik. Rata-rata persentase dari pertemuan pertama sampai dengan pertemuan ketigayaitu $81,33 \%$. Dengan demikian, rata-rata tersebut berada di atas $80 \%$. Walaupun pada awal pelaksanaan pembelajaran melalui model TAPPS mengalami sedikit hambatan sebab pembelajaran tersebut merupakan hal yang baru bagi siswa sehingga butuh waktu untuk penyesuaian. Akan tetapi, hambatan tersebut secara berangsur-angsur dapat berkurang sebab siswa mulai tertarik dan terbiasa 
dengan penerapan model pembelajaran TAPPS. Adanya kerjasama, diskusi dan tukar pendapat yang dilakukan oleh siswa memudahkan mereka dalam menyelesaikan masalah yang diberikan oleh guru.

Pada pembelajaran TAPPS dibutuhkan dua orang siswa yang berperan sebagai listener dan problem solver untuk bekerja sama ketika menyelesaikan suatu masalah. Hal ini sejalan dengan teori yang dikemukakan oleh Piaget dan Vygotsky (Ibrahim dan Nur dalam Rusman, 2010) dimana siswa ditekankan untuk aktif bekerja sama dalam kelompok secara berpasangan. Pada proses ini terjadi interaksi antara siswa dengan masing-masing pasangannya yang saling bekerja sama, mendukung, membantu dan melengkapi antara satu dengan lainnya sehingga mereka sama-sama mengetahui solusi dari permasalahan yang sedang dihadapi.

Pembelajaran TAPPS dimulai dengan adanya suatu masalah yang harus diselesaikan setiap pasangan. siswa sebagai problem solver diminta untuk mencari solusi dari masalah yang dihadapi dan menyampaikan semua pendapat dan pemikirannya selama proses menyelesaikan masalah kepada siswa yang bertugas sebagai listener. Di pihak lain, tugas listener yaitu memberikan koreksi seluruh proses penyelesaian masalah dari problem solver dan memberikan petunjuk pemecahan masalah dengan cara bertanya tentang hal-hal yang berkaitan dengan pemecahan masalah tersebut dan tidak langsung menunjukkan solusi pemecahan masalah yang dimaksud. Setelah masalahnya terselesaikan, kedua siswa yang saling berpasangan tersebut diminta untuk bertukar tugas dan diberikan masalah yang berbeda dari sebelumnya sehingga masing-masing memiliki kesempatan yang sama.

Dari analisis data yang telah diuraikan di atas, dapat ditarik sebuah kesimpulan bahwa pembelajaran dengan model TAPPS adalah salah satu pembelajaran yang efektif sehingga dapat menjadi alternatif guru dalam meningkatkan disposisi matematis siswa.Pada penelitian ini, ditemukan beberapa keunggulan pembelajaran dengan menggunakan model TAPPS yaitu (1) siswa lebih aktif dan antusias dalam mengikuti setiap proses pembelajara; (2) terjadi interaksi antara siswa yang satu dengan yang lainnya sehingga mereka saling belajar ketika memilih stategi untuk memecahkan suatu masalah; dan (3) pembelajaran model ini menuntut siswa untuk berpikir keras secara mandiri dalam mencari solusi suatu masalah yang mengakibatkan pola berpikir siswa menjadi jauh lebih terstruktur.

Di samping memiliki keunggulan, model TAPPS juga memiliki beberapa kelemahan, diantaranya: (1) siswa sulit menyampaikan gagasan yang ada dipikirannya; dan (2) listener terkadang mengalami kesulitan ketika menuntun atau memberi petunjuk sekaligus mengoreksi problem solver ketika memecahkan suatu masalah. Akan tetapi, kekurangan-kekurangan tersebut dapat diminalisir dengan adanya bantuan dan guru untuk memandu jalannya proses diskusi.

\section{PENUTUP}

Berdasarkan uraian di atas, maka dapat ditarik kesimpulan bahwa penerapan model pembelajaran TAPPS pada siswa di SD NU Nawa Kartika dapat meningkatkan disposisi matematis. Pada penelitian ini, peningkatan disposisi matematisnya adalah 0,37 dengan klasifikasi sedang. Peneliti memberikan saran bagi guru bahwa model TAPPS dapat menjadi alternatif pembelajaran yang dapat digunakan untuk meningkatkan disposisi matematis siswa. Hal ini dikarenakan dengan adanya variasi pembelajaran proses pembelajaran akan lebih menarik dan siswa lebih aktif mengikuti pelajaran matematika. Selain itu, guru juga dapat berinisiatif dan kreatif mendayagunakan lingkungan sekitar dalam pembelajaran sehingga siswa lebih mudah mempelajari dan memahami materi yang diberikan sehingga pembelajaran akan lebih berkesan dan bermakna bagi siswa.

\section{UCAPAN TERIMAKASIH}

Penulis menghaturkan terimakasih kepada Galih Kurniadi, M. Pd. dan Latifah Nur Ahyani, S. Psi., M. A. selaku partner peneliti yang telah memberikan bantuan dan kerjasama kepada penulis. Selain itu Dr. Mamik Indaryanti, M. S. Selaku kepala Lembaga Penelitian Universitas Muria Kudus yang telah memberikan petunjuk, arahan, dan bimbingan serta kerjasama kepada penulis. Tak lupa penulis juga menyampaikan terimakasih kepada redaktur Suska Journal Mathematics Educationi dan reviewer atas kesempatan yang diberikan kepada penulis untuk mempublikasikan artikel, serta semua pihak yang telah memmbantu penulis selama melaksanakan kegiatan penelitian. Semoga artikel ini bermanfaat dan ikut menambah wawasan dalam meningkatkan kualitas pendidikan.

\section{DAFTAR PUSTAKA}


Barkley, Elizabeth E., Cross, K. Patricia \& Major, Clair Howell. (2012).Collaborative LearningTechniques. [Terjemahan]. Penerjemah: Narulita Yusron. Bandung: Nusa Media.

Depdiknas. (2006). Kurikulum Tingkat Satuan Pendidikan. Jakarta: Departemen Pendidikan Nasional. . (2008). Kurikulum Tingkat Satuan Pendidikan. Jakarta: Departemen Pendidikan Nasional.

Hidayah, N. (2014). Peningkatan Kemampuan Generalisasi Matematis dan Disposisi Matematis Siswa melalui Pembelajaran Matematika menggunakan Metode Penemuan Terbimbing. Skripsi. UIN Sunan Kalijaga. Tidak Diterbitkan].

Krismanto, Al. (2003). Beberapa Teknik, Model, dan Strategi dalam Pembelajaran Matematika. Pelatihan Instruktur atau Pengembang SMU. Yogyakarta: PPPG Matematika.

Mahmudi, A. (2010). Mengukur Kemampuan Berpikir Kreatif Matematis. Konferensi Nasional Matematika XV UNIMA Manado, Manado.

Mahmuzah, R., Ikhsan, M. \& Yusrizal. 2014. Peningkata Kemampuan Berpikir Kritis dan Disposisi Matematis Siswa SMP dengan Menggunakan Pendekatan Problem Posing. Jurnal Didaktik Matematika ISSN: 2355-4185. Vol 1 No: 2, hlm. 43-53

Meltzer, D. E. (2002). The Relationship Between Mathematics Preparation and Copcetual Learning Gain in Physics. Vol 70. hlm 1259-1268.

Merz. A. (2009). Teaching for Mathematical Dispositions as Well as for Understanding: The difference Between Reacting to and Advocating forDispositional Learning. The Journal of Education Thought, Spring 43(1) ProQuest ResearchLibrary page. 265

Muslich, M. (2008). KTSP Dasar Pemahaman dan Pengembangan. Jakarta. PT. Bumi Aksara.

Naryestha, K. E. Wiarta, W. Dan Wayan, I. S. (2014). Model Pembelajaran Kooperatif TAPPS Berbantuan LKS Berpengaruh Terhadap Hasil Belajar Matematika. E-Journal Mombar PGSD Universitas Ganesha. Vol: 2 No: 1.

NCTM. 1989.Curriculum and Evaluation Standards for School Mathematics. Reston, VA: Authur.

Nila, K. (2010). Peningkatan Kemamuan Pemahaman, Pemecahan Masalah, dan Disposisi Matematis Siswa SMP melalui Pendekatan Pendidikan Matematika. Disertasi. Universitas Pendidikan Indonesia. [Tidak Diterbitkan].

Permana, Y. (2010). Mengembangkan Pemahaman, Komunikasi dan Disposisi matematis. Tesis. Universitas Pendidikan Indonesia. [Tidak Diterbitkan].

Ruseffendi, E.T. (2010). Dasar-dasar Penelitian Pendidikan \& Bidang Non-Eksakta Lainnya. Bandung: Tarsito

Rusman. (2010). Model-model Pembelajaran. Bandung: Mulia Mandiri Press.

Sumarmo, U. (2005). Pembelajaran Matematika untuk Mendukung Pelaksanaan Kurikulum Tahun 2002 Sekolah Menengah. Seminar Pendidikan Matematika. Bandung: Universitas Pendidikan Indonesia.

Syaban, M. (2009). Menumbubkembangkan Daya dan Disposisi Matematis Siswa Sekolab Menengah Atas melalui Pembelajaran Investigasi. [Online]. Tersedia :bttp:/ file.upiedu/Direktori/Jurnal/EDUCATIONIST/ Vol._III_Ni._2Juli_2009/08_Mumun_Syaban.pdf. [30 November 2015] 